\title{
Roadkill of Eastern Newts (Notophthalmus viridescens) in a protected area in Quebec
}

\author{
David C. Seburn ${ }^{1, *}$, Elena Kreuzberg ${ }^{2}$, and Leah Viau ${ }^{2}$ \\ ${ }^{1}$ Seburn Ecological Services, 2710 Clarenda Street, Ottawa, Ontario K2B 7S5 Canada \\ ${ }^{2}$ Canadian Parks and Wilderness Society, Ottawa Valley Chapter, 15 rue Taschereau, suite 240, Gatineau, Quebec J8Y 2 V6 \\ Canada \\ *Corresponding author: davidseburn@sympatico.ca
}

Seburn, D.C., E. Kreuzberg, and L. Viau. 2019. Roadkill of Eastern Newts (Notophthalmus viridescens) in a protected area in Quebec. Canadian Field-Naturalist 133(2): 101-104. https://doi.org/10.22621/cfn.v133i2.2219

\begin{abstract}
Roadkill is a threat to populations of many amphibian species, including Eastern Newt (Notophthalmus viridescens), which is widespread in eastern Canada and the northeastern United States. Little is known about the level of road mortality experienced by dispersing Eastern Newts in Canada. During extensive road surveys from May to October 2016 and 2017,279 dead Eastern Newt efts were found on roads in Gatineau Park, Quebec. We found 107 dead Eastern Newts along a $425 \mathrm{~m}$ section of road in 2016, but only 30 dead individuals at the same location in 2017. Thus, although the amount of roadkill can vary annually, it may pose a significant threat to the species in some areas.
\end{abstract}

Key words: Eastern Newt; Notophthalmus viridescens; road ecology; salamander; hotspot; Gatineau Park

\section{Introduction}

Roadkill is a threat for many species of amphibians (Ashley and Robinson 1996; Andrews et al. 2008), and they are often the vertebrate group most commonly killed on roads (Ashley and Robinson 1996; Smith and Dodd 2003; Glista et al. 2008). Traffic mortality can have a negative effect on amphibian populations (Fahrig et al. 1995; Rytwinski and Fahrig 2012). Although roadkill numbers are often greatest for frogs and toads, roadkill can also be a threat for salamanders (Clevenger et al. 2001; Gibbs and Shriver 2005; Pagnucco et al. 2012). Salamanders may remain immobile on roads when a vehicle approaches, increasing their risk of being run over (Mazerolle 2004). Mortality of $>10 \%$ of the adult population of Spotted Salamanders (Ambystoma maculata) can lead to population decline and possibly extirpation (Gibbs and Shriver 2005).

Here we report on substantial roadkill of Eastern Newt (Notophthalmus viridescens), a species widespread in eastern Canada and the northeastern United States (Cook 1984). Eastern Newt is a pond breeding salamander with a complex and variable life cycle. The typical life cycle of Eastern Newt includes four distinct stages: egg, aquatic larva, terrestrial juvenile or eft, and adult (Gill 1978). After larvae transform, the juvenile eft stage disperses from the breeding ponds in late summer and early fall (Gill 1978).
The eft stage can last for three or more years (Healy 1974), after which maturing efts return to breeding ponds (Hurlbert 1969). Adults may remain in aquatic habitats or hibernate on land (Hurlbert 1969; Gill 1978). The eft stage is the primary growth and dispersal stage in the life cycle, whereas emigrating adults are believed to return to the same breeding ponds repeatedly (Gill 1978). It is unclear how far efts can disperse, but they have been documented to move up to $80 \mathrm{~m}$ in a single night (Roe and Grayson 2008) and take up to a year to migrate $800 \mathrm{~m}$ (Healy 1974, 1975). The multi-year maturation and dispersal period allows Eastern Newts to colonize newly formed and distant wetlands (Semlitsch 2008) and represents a vulnerable life history stage (Gill 1978). When migration or dispersal routes cross roads, mortality can occur.

\section{Methods}

Road surveys were conducted by car in Gatineau Park, Quebec $\left(45.5^{\circ} \mathrm{N}, 75.8^{\circ} \mathrm{W}\right)$ along Meech Lake Road, Gatineau Parkway, Dunlop Road, and Fortune Lake Parkway for a total of $\sim 20 \mathrm{~km}$. Gatineau Park covers an area of 36131 ha and is managed by the National Capital Commission (NCC 2005). Most of the roads within the park date back to the 1950s or earlier (NCC 2005), but upgrades have occurred over the last several decades. All roads surveyed have

$\overline{\text { A contribution }}$ towards the cost of this publication has been provided by the Thomas Manning Memorial Fund of the Ottawa Field-Naturalists' Club. 
existed for several decades and were paved, two-lane roads. Roadside habitats varied along the roads, but typically the shoulder was narrow with adjacent forests coming within a few metres of the road.

The car was driven at $\sim 30-35 \mathrm{~km} / \mathrm{h}$ and two surveyors participated in each survey, scanning both the road surface and road shoulder. All dead animals were removed from the road or road shoulder to prevent double counting in a subsequent survey. Surveys were conducted in the morning before scavengers could remove all the roadkill from the previous day or night. Surveys were typically conducted twice a week. Surveys were not conducted during heavy rainfall, but were conducted during light to moderate rain. In addition to driving surveys, walking surveys were conducted at eight locations in the park along the survey route. Walking survey locations were not randomly selected, but based on proximity to designated parking areas in the park to ensure safe parking as well as safety for walking along the roads. Each walking transect was $\sim 90 \mathrm{~m}$ in each direction from the stopping point, but extended if high numbers of roadkill were observed. All vertebrate species were recorded, but only results for Eastern Newt are presented here.

Weather data from the closest weather station, Chelsea, Quebec, were obtained to compare rainfall patterns with observed roadkill. On dates where no weather data were available from the Chelsea station, data were obtained from the Ottawa International Airport station, $\sim 25 \mathrm{~km}$ to the southeast.

\section{Results and Discussion}

We conducted 37 surveys from 12 May until 3 October 2016 and 32 surveys from 15 May to 16 October 2017, for a total of 69 surveys. We found 150 dead Eastern Newts in 2016, and 129 in 2017, for a total of 279. All of the dead Eastern Newts were ju- veniles (efts). Dead Eastern Newts were found on the road from 18 July to 3 October in 2016, and from 15 May to 8 October in 2017 (Figure 1). The peak mortality events were 36 Eastern Newts on 28 July 2016 and 30 Eastern Newts on 5 June 2017 (Figure 1).

High counts of dead Eastern Newts likely coincide with peak dispersal events, which usually occur in late summer following rains (Gill 1978; Paton et al. 2000; Leclair et al. 2005). The peak mortality event on 28 July 2016 does not appear to be connected to rainfall as there was no rain on 28 July or the two previous days, although there was $5.2 \mathrm{~mm}$ of rain on 25 July (Government of Canada 2019). Rainfall data are missing for the first five days of June 2017, but only $1.0 \mathrm{~mm}$ of rainfall was recorded on 4 June 2017, at the Ottawa International Airport. No rainfall was recorded on 3 June and only $0.2 \mathrm{~mm}$ on 2 June 2017 .

Over $90 \%$ of Eastern Newts were found during the walking surveys. We found 107 of the $150(71.3 \%)$ dead Eastern Newts in 2016 along a 425-m section of Meech Lake Road. Smaller numbers of dead Eastern Newts were found at other walking survey locations. The main mortality site was associated with a small creek and numerous wetlands. Habitat at the main mortality site was not obviously different from that at other locations in the park, as creeks, wetlands, and forest are widespread, and the park contains 50 lakes and "several hundred ponds" (NCC 2005). A peak of 30 dead Eastern Newts was found in this mortality "hotspot" on 28 July. Secondary peaks occurred on 12 August (15 Eastern Newts) and 18 August (18 Eastern Newts).

Fewer dead Eastern Newts were found in the main hotspot in 2017: only 30 (25.4\%) of the 129 individuals found that year. A peak of 11 dead Eastern Newts was found in the hotspot on 29 June; no more than five mortalities were found on other survey days. There are many possible reasons why fewer dead Eastern

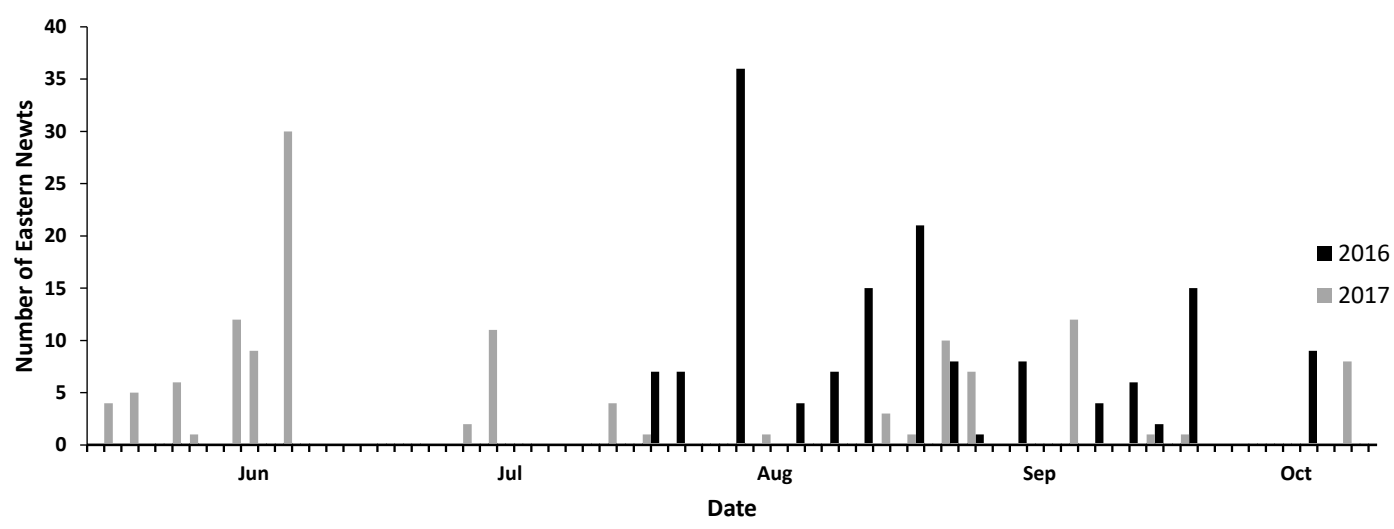

FIGURE 1. Number of Eastern Newt (Notophthalmus viridescens) efts found dead on roads in Gatineau Park, Quebec, during road surveys from 12 May to 3 October 2016 and from 15 May to 16 October 2017. 
Newts were found in 2017: survey timing not matching peak dispersal events, fewer dispersing efts, or weather conditions limiting dispersal. It does not appear that rainfall is responsible for fewer Eastern Newts being found dead at the main hotspot in 2017, as 2017 was a rainier spring and summer, with 344.6 $\mathrm{mm}$ from May to August, compared with only 185.4 $\mathrm{mm}$ during the same period in 2016 (Government of Canada 2019).

Over the two years, 137 dead Eastern Newts were found at the main hotspot. Likely many other Eastern Newts were killed there, but not observed, given their small size, obliteration by vehicles, and removal by scavengers. Unlike many other salamanders, Eastern Newts are active during the day (Petranka 1998) when motorists are more likely to travel park roads.

Other researchers have reported significant numbers of dead Eastern Newts on roads. Mitchell (2000) found 182 dead Eastern Newts along a $250-\mathrm{m}$ stretch of road on 4 October 1991 in Virginia. An additional 24 dead Eastern Newts were found at the same site over the course of three subsequent surveys in 1992 (Mitchell 2000). The large number of mortalities in 1991 may have been a chance event, or the result of a large production of efts that year (Mitchell 2000). The results from Virginia are similar to our results from Quebec, i.e., substantially different numbers of observed roadkill at the same site in different years. Such results emphasize the fact that one year of road surveys will not always provide a complete picture of the overall rate of roadkill. Individuals in our study were not measured, but were assumed to be recently metamorphosed juveniles dispersing from the natal wetland.

The population-level effect of roadkill on salamanders is not well known. Our results indicate that many Eastern Newts can be killed on roads in some areas. Although efts likely have a relatively high rate of natural mortality, it is unclear what effect the additive mortality of roadkill has on populations. Further research on this topic is warranted.

\section{Acknowledgements}

This study was undertaken by the Canadian Parks and Wilderness Society (CPAWS) Ottawa Valley as part of a larger project on road ecology in eastern Ontario and western Quebec. We thank the numerous volunteers who assisted with the road surveys. CPAWS Ottawa Valley is grateful for financial support from the North American Partnership for Environmental Community in Action, the Clean Tech Internship Program of Colleges and Canadian Institutes, and the Community Environmental Grant Program of the City of Ottawa. A permit to conduct research in Gatineau Park was issued by the National Capital Commission.

\section{Literature Cited}

Andrews, K.M., J.W. Gibbons, and D.M. Jochimsen. 2008. Ecological effects of roads on amphibians and reptiles: a literature review. Urban Herpetology 3: 121-143.

Ashley, E.P., and J.T. Robinson. 1996. Road mortality of amphibians, reptiles and other wildlife on the Long Point Causeway, Lake Erie, Ontario. Canadian FieldNaturalist 110: 403-412. Accessed 30 July 2019. https:// biodiversitylibrary.org/page/34343309.

Clevenger, A.P., M. McIvor, D. McIvor, B. Chruszcz, and K. Gunson. 2001. Tiger Salamander, Ambystoma tigrinum, movements and mortality on the Trans-Canada Highway in southwestern Alberta. Canadian Field-Naturalist 115: 199-204. Accessed 30 July 2019. https:// biodiversitylibrary.org/page/34995273.

Cook, F.R. 1984. An Introduction to Canadian Amphibians and Reptiles. National Museum of Natural Sciences, Ottawa, Ontario, Canada.

Fahrig, L., J.H. Pedlar, S.E. Pope, P.D. Taylor, and J.F. Wegner. 1995. Effect of road traffic on amphibian density. Biological Conservation 73: 177-182. https://doi. org/10.1016/0006-3207(94)00102-V

Gibbs, J.P., and W.G. Shriver. 2005. Can road mortality limit populations of pool-breeding amphibians? Wetlands Ecology and Management 13: 281-289. https://doi .org/10.1007/s11273-004-7522-9

Gill, D.E. 1978. The metapopulation ecology of the Redspotted Newt, Notophthalmus viridescens (Rafinesque). Ecological Monographs 48: 145-166. https://doi.org/10. 2307/2937297

Glista, D.J., T.L. DeVault, and J.A. DeWoody. 2008. Vertebrate road mortality predominantly impacts amphibians. Herpetological Conservation and Biology 3: 77-87.

Government of Canada. 2019. Historical data: Chelsea and Ottawa MacDonald-Cartier Int'l A. Environment and Natural Resources, Weather, Climate and Hazard, Ottawa, Ontario, Canada. Accessed 25 March 2019. http://climate.weather.gc.ca/historical_data/search historic_data_e.html.

Healy, W.R. 1974. Population consequences of alternative life histories in Notophthalmus v. viridescens. Copeia 1974: 221-229. https://doi.org/10.2307/1443027

Healy, W.R. 1975. Terrestrial activity and home range in efts of Notophthalmus viridescens. American Midland Naturalist 93: 131-138. https://doi.org/10.2307/2424111

Hurlbert, S.H. 1969. The breeding migrations and interhabitat wandering of the vermilion-spotted newt Notophthalmus viridescens (Rafinesque). Ecological Monographs 39: 465-488. https://doi.org/10.2307/1942356

Leclair, R., M.H. Leclair, and M. Levasseur. 2005. Size and age of migrating eastern red efts (Notophthalmus viridescens) from the Laurentian Shield, Quebec. Journal of Herpetology 39: 51-57. https:/doi.org/10.1670/ 0022-1511(2005)039[0051:saaome]2.0.co;2

Mazerolle, M.J. 2004. Amphibian road mortality in response to nightly variations in traffic intensity. Herpetologica 60: 45-53. https://doi.org/10.1655/02-109

Mitchell, J.C. 2000. Mass mortality of red-spotted newts (Notophthalmus viridescens viridescens Rafinesque) on a central Virginia road. Banisteria 15: 45-47. 
NCC (National Capital Commission). 2005. Gatineau Park master plan. National Capital Commission, Ottawa. Accessed 16 March 2019. http://ncc-ccn.gc.ca/our-plans/ gatineau-park-master-plan.

Pagnucco, K.S., C.A. Paszkowski, and G.J. Scrimgeour. 2012. Characterizing movement patterns and spatiotemporal use of under-road tunnels by Long-toed Salamanders in Waterton Lakes National Park, Canada. Copeia 2012: 331-340. https://doi.org/10.1643/CE-10-128

Paton, P., S. Stevens, and L. Longo. 2000. Seasonal phenology of amphibian breeding and recruitment at a pond in Rhode Island. Northeastern Naturalist 7: 255-269. https://doi.org/10.2307/3858358

Petranka, J.W. 1998. Salamanders of the United States and Canada. Smithsonian Institution Press, Washington, DC, USA.

Roe, A.W., and K.L. Grayson. 2008. Terrestrial move- ments and habitat use of juvenile and emigrating adult Eastern Red-spotted newts, Notophthalmus viridescens. Journal of Herpetology 42: 22-30. https://doi.org/ 10.1670/07-040.1

Rytwinski, T., and L. Fahrig. 2012. Do species life history traits explain population responses to roads? A metaanalysis. Biological Conservation 147: 87-98. https:// doi.org/10.1016/j.biocon.2011.11.023

Semlitsch, R.D. 2008. Differentiating migration and dispersal for pond-breeding amphibians. Journal of Wildlife Management 72: 260-267. https://doi.org/10.2193/ 2007-082

Smith, L.L., and C.K. Dodd, Jr. 2003. Wildlife mortality on US highway 441 across Paynes Prairie, Alachua County, Florida. Florida Scientist 66: 128-140.

Received 1 February 2019

Accepted 30 July 2019 